\title{
Contribution of well logging and seismic reflection to the Jurassic petroleum system characterization in the Chotts zone (Southern Tunisia)
}

\author{
Rihab Guellala ${ }^{1,3} \cdot$ Kaoula Abdelmoumen $^{1,3} \cdot$ Benen Sarsar Naouali ${ }^{2,3} \cdot$ Ali Mahroug $^{2}$
}

Received: 21 August 2019 / Accepted: 25 March 2020 / Published online: 11 April 2020

(c) The Author(s) 2020

\begin{abstract}
In the Chotts zone central part (southern Tunisia), the Jurassic series are interesting for hydrocarbon exploration. However, these series' composition and geometry are little studied to propose prospection programs. Using boreholes and seismic reflection data, the present study aims a better characterization of the Jurassic series in the Chotts zone central part, in view of petroleum prospects identification. The analysis of the lithological columns and their corresponding well logs highlights an interesting petroleum system: The Tithonian, Kimmeridgian and Oxfordian carbonated deposits are the main reservoirs formations, whereas the Kimmeridgian and Callovian clays constitute the source rocks. The seal rocks are composed of the Jurassic clayey intercalations. Forty-four seismic reflection profiles calibrated using the time-depth relation in petroleum wells are interpreted in this study. The reflectors corresponding to the Malm, Dogger and Lias tops are identified and picked on the different seismic profiles. The isochrone, isobath and isopach maps subsequently deduced disclose important tectonic features that affect the Jurassic series in the Chotts zone and control their geometry. They highlight two sunken zones separated by a raised structure. This structure corresponds to an anticline, overturned toward the south, limited by E-W major faults and truncated by other oriented NW-SE. It constitutes an excellent trap structure where five interesting prospects are precisely delimited. Furthermore, the determined tectonic accidents may facilitate the migration of oil from Jurassic source rocks. The findings of this study can help for better understanding of the Jurassic petroleum system in the Chotts area and guide enormously its exploration.
\end{abstract}

Keywords Tunisia $\cdot$ Chotts zone central part $\cdot$ Borehole $\cdot$ Seismic reflection $\cdot$ Petroleum system

\section{Introduction}

Compared to its neighboring countries (Algeria and Libya), the oil exploration in Tunisia can be considered to be immature, with only 1050 wells drilled from 1932 to 2008. In some cases, large permits may have just had a few exploratory wells drilled. It is the case of the Chotts zone central

Rihab Guellala

rihabguellala@gmail.com

1 Laboratoire de Géoressources, CERTE, Pôle Technologique de Borj Cédria, 8020 Soliman, Tunisia

2 Entreprise Tunisienne d'Activités Pétrolières, Cherguia II, Tunis, Tunisia

3 Unité de Recherches de Géophysique Appliquée aux Minerais et aux Matériaux, Faculté des Sciences de Tunis, Tunis, Tunisia part, which is the least investigated area in the southern Tunisia; only W1 and W2 petroleum wells are implanted in this area covering a superficies of $3032 \mathrm{~km}^{2}$. These wells have proven the petroleum interest of the Jurassic formations containing carbonate reservoirs (Dakhelpour-Ghoveifel et al. 2019; Olayiwola and Dejam 2019). In fact, in W1 well, a Kimmeridgian reservoir situated between 2530.5 and $2759 \mathrm{~m}$ depth produced $100 \mathrm{~L} / \mathrm{h}$ (ETAP 2009). Moreover, petroleum wells situated toward the east, in Metouia block, reveal that the Callovian clays present good characteristics of a source rock: TOC (total organic carbon) $=2.6 \%$ and PP $($ petroleum potential $)=10 \mathrm{~kg} / \mathrm{T}($ ETAP 2006) .

The previous geological studies which were interested in the Chotts zone had mainly for objective the surface tectonic structures ( Abdeljaoued 1983; Rabia 1984; Zargouni 1985; Abbes and Zargouni 1986; Ben Ayed 1986; Ghanmi et al. 1988; Fakraoui 1990; Abbes and Tlig 1991; Chihi et al. 1992; Bedir 1995; Bouaziz 1995; Zouari 1995; Boukadi 
et al. 1998, etc.). Recently, structural studies have integrated seismic reflection and gravity data to reconstruct the deep structuration and the geodynamic evolution of this area and its surroundings (Gabtni et al. 2011; Said et al. 2011; Zouaghi et al. 2011; Gharbi et al. 2014; El Amari et al. 2016; Tanfous Amri et al. 2017, etc.). The Jurassic petroleum system has been neglected in the different precedent works (Fig. 1); thus, the proposal of this study aims a detailed knowledge of this system in the Chotts zone central part. Its realization will have different advantages: (1) identification of reservoirs, source rocks and seal rocks through the analysis of lithological columns and well logs; (2) reconstitution of the geometry of the Jurassic series by benefiting from a good number of seismic reflection profiles; (3) delimitation of interesting zones for petroleum exploration; (4) application of two geophysical methods, namely well logging and seismic reflection which are successfully applied in recent studies dealing with petroleum system characterization

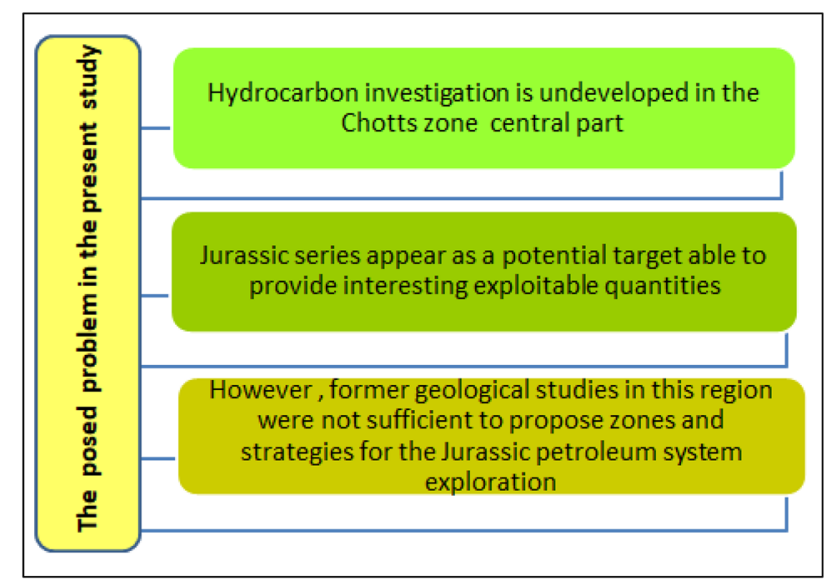

Fig. 1 General sketch of the problem posed in the present study
(Mohamed et al. 2016; Fajana et al. 2018; Ameloko et al. 2019). However, the present study has the disadvantage of being limited to the central part of the Chotts zone where seismic and well data are accessible.

\section{Geographical and geological context}

The study area covers the central part of the Chotts region corresponding to the northern part of the Kebili Governorate. It is limited by Gafsa to the north, Gabes to the east and Tozeur to the west (Fig. 2).

Geologically, this block belongs to the Chotts belt (Fig. 3) which is defined as an ENE-WSW megaanticlinal (Zargouni 1985; Fakraoui 1990; Bouaziz 1995) affected by Gafsa and Negrine-Tozeur corridors (Zargouni 1985; Fakraoui 1990). Its southern flank is the Tebaga of Kebili belt, whereas the northern flank corresponds to the Chareb belt (Fakraoui 1990).

The Chareb belt is constituted by a series of dissymmetric folds (Jebels Sidi Bouhlel, Torrich, Hachichina, etc.) having an E-W general direction. The Gafsa corridor has controlled the sedimentation of this belt's upper Cretaceous series and has caused variations in thickness and facies within this series (Abdallah 1987).

The Tebaga of Kebili chain is defined as a E-W monoclinal with a slight dip to the southwest (Fakraoui 1990). Its eastern part is truncated by N-S, E-W and NW-SE normal faults (Zargouni 1985; Bouaziz 1995).

The geological outcrops are mainly Quaternary and Cretaceous in age. Jurassic series designed by Nara formation (Burollet 1956) are recognized from the petroleum wells W1 and W2. Only the upper Nara (Oxfordian to Tithonian) and the upper part of the middle Nara (Callovian) are reached by these wells.

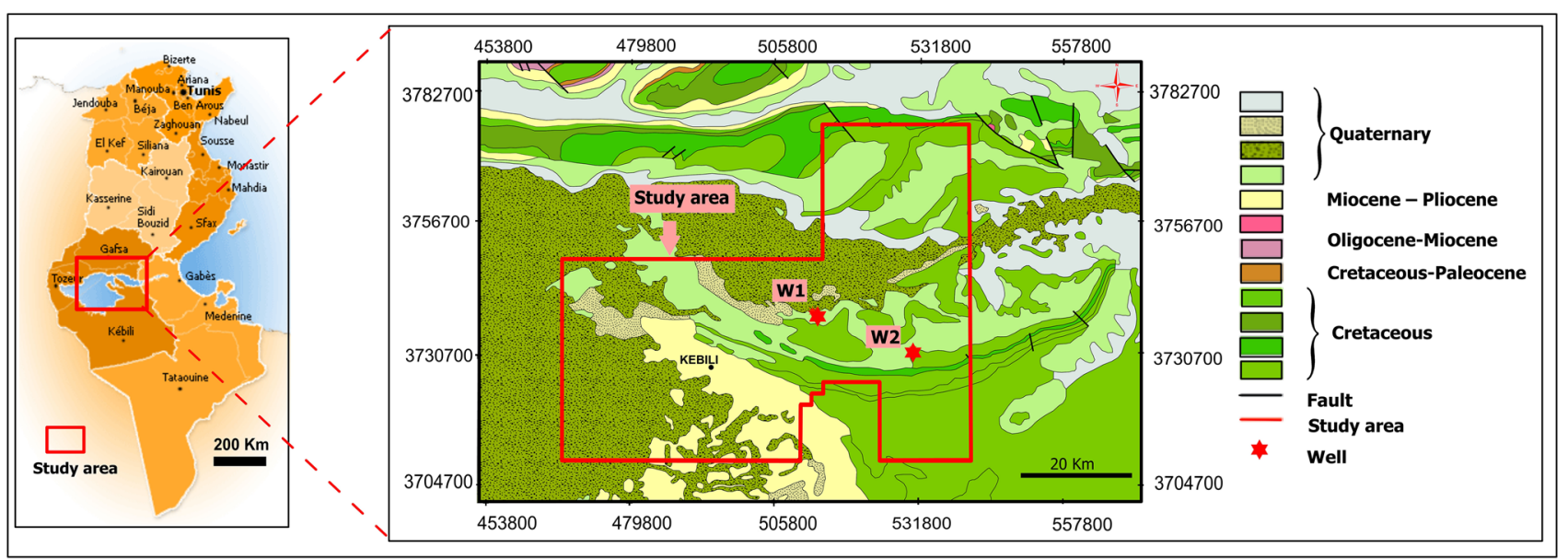

Fig. 2 Study area and petroleum wells location 


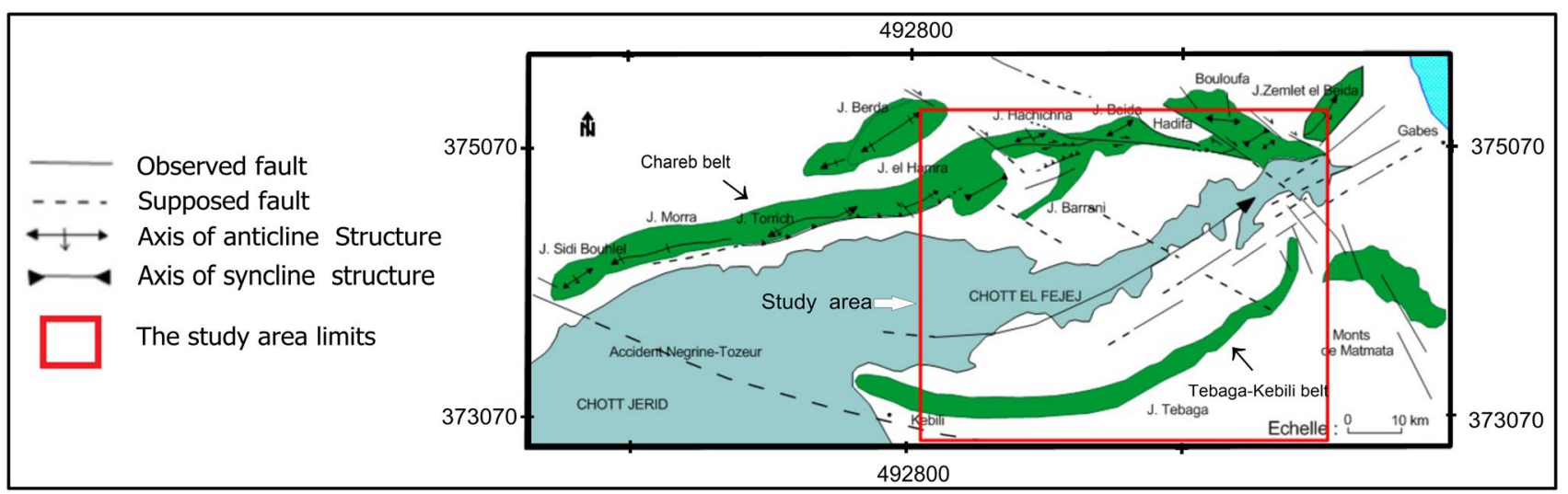

Fig. 3 Chotts belt structural map (Zargouni 1985, modified)

\section{Data and methods}

In this study, boreholes data and seismic reflection profiles are exploited.

The boreholes data consist of the lithostratigraphic columns and the corresponding well logs in the W1 and W2 petroleum wells.

Well log is a continuous recording of physical parameters along a borehole (Desbrandes 1968). The most appropriate name of this recording is a wireline geophysical well log, conveniently shortened to well $\log$ or $\log$.

In the present work, the studied physical parameters are the natural radioactivity and the resistivity.

The Gamma ray log represents the rocks natural radioactivity measures (Serra 1985). The clays are particularly rich in radioactive elements: uranium, thorium and potassium. Hence, the Gamma ray log is a very powerful tool to differentiate between clayey and non-clayey layers (Bassiouni 1994).

Available resistivity logs are measured by the dual laterolog (DLL) which is a combination of two tools and can be run in a deep penetration (LLd) and shallow penetration (LLs) mode (Nam et al. 2010; Saboorian-Jooybari et al. 2015, 2016).

The LLs allow to determinate the resistivity of the transition zone (Ri), between the invaded and the uninvaded zones, whereas the LLD measures the uninvaded zone resistivity (Rt) (Rider 1996).

Dual laterolog resistivity logs provide a precise delimitation of the reservoirs layers; if the LLd curve indicates a high response and it is remarkably spaced from the LLs curve, the geological formation is permeable.

The seismic reflection method estimates the properties of the subsurface layers from reflected seismic waves (Cagniard 1962). It uses a source of energy as seismic vibrator or dynamite explosion to generate acoustic waves that will be reflected when they encounter a boundary between two different materials having different acoustic impedances. The reflected waves are recorded by seismometers and plotted on a seismic section after several processings (Robein 1999; Upadhyay 2004) such as filtering, deconvolution, stacking and migration.

The reflectors corresponding to the Lias, Dogger and Malm series tops have been identified and picked on seismic profiles all over the area. Seismic calibration was performed using W1, W2 and W3 petroleum wells. Seismic horizons and facies have been tied using the time-depth relation (Table 1).

The interpolation between the interpreted seismic sections leads to the isochrones maps construction. Isobaths maps were then deduced after the conversion from timesections to depth-sections using the available velocity data.

Forty-four 2D seismic reflection sections (Fig. 4), acquired by oil industries (MOBIL and MOL) in the Nefzaoua area during three seismic surveys (KEB in 1992, MTB and MT in 1974), are interpreted in this study using SMT software available at the "Entreprise Tunisienne d'Activités Pétrolières (ETAP)".

\section{Results and discussions}

\section{Well logging contribution}

The analysis of well logs corresponding to the Berriasian deposits (Fig. 5) which covers the Jurassic series highlights

Table 1 Time-depth conversion

\begin{tabular}{llll}
\hline Well & Formation top & $\begin{array}{l}\text { Formation depth } \\
(\text { sea level })(\mathrm{m})\end{array}$ & $\begin{array}{l}\text { Two-way travel } \\
\text { time (TWT) } \\
(\mathrm{ms})\end{array}$ \\
\hline W1 & Malm & 1855 & 1110 \\
W2 & Dogger & 2200 & 1250 \\
W3 & Lias & 3212 & 1658.8 \\
\hline
\end{tabular}




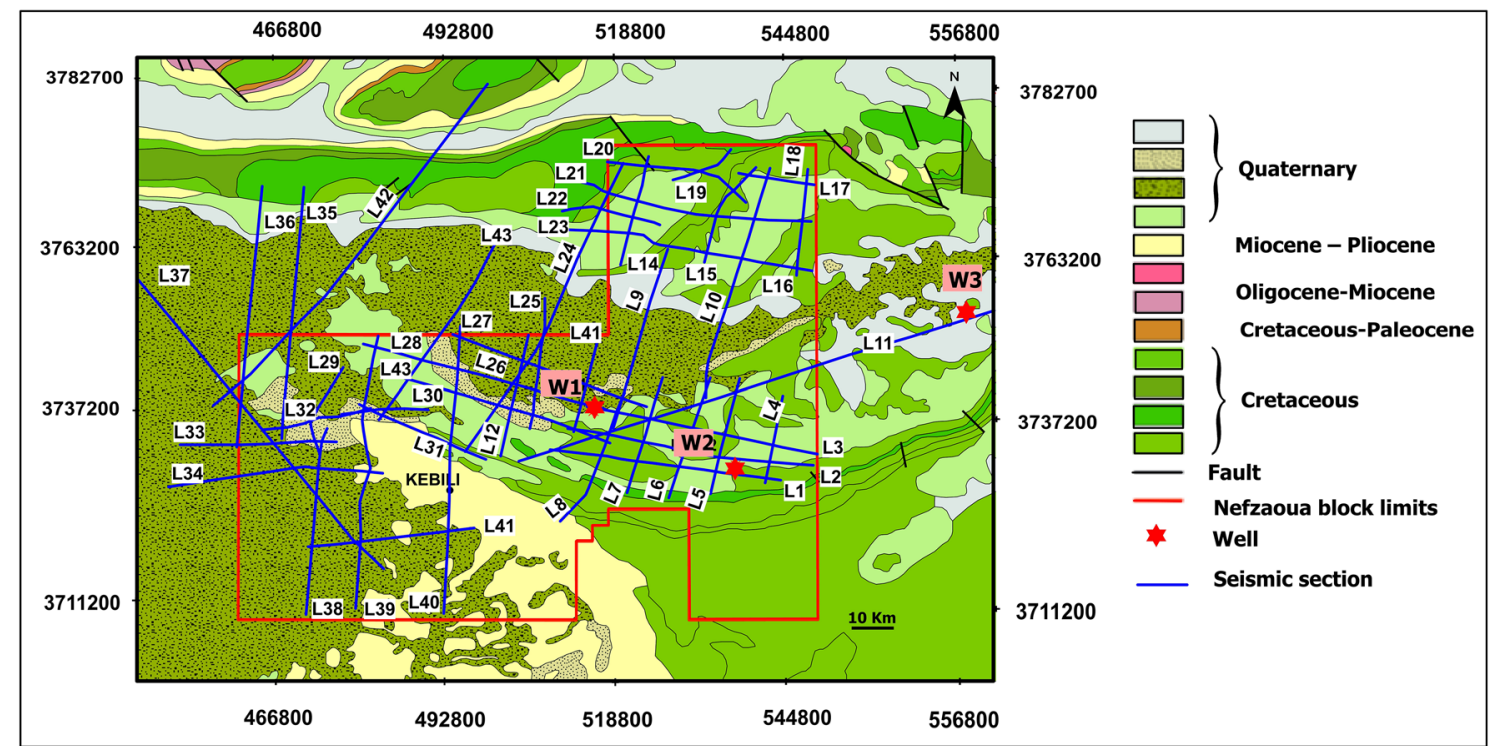

Fig. 4 Seismic reflection profiles location

Fig. 5 Characterization of the Berriasian series using well logs (W1 well)

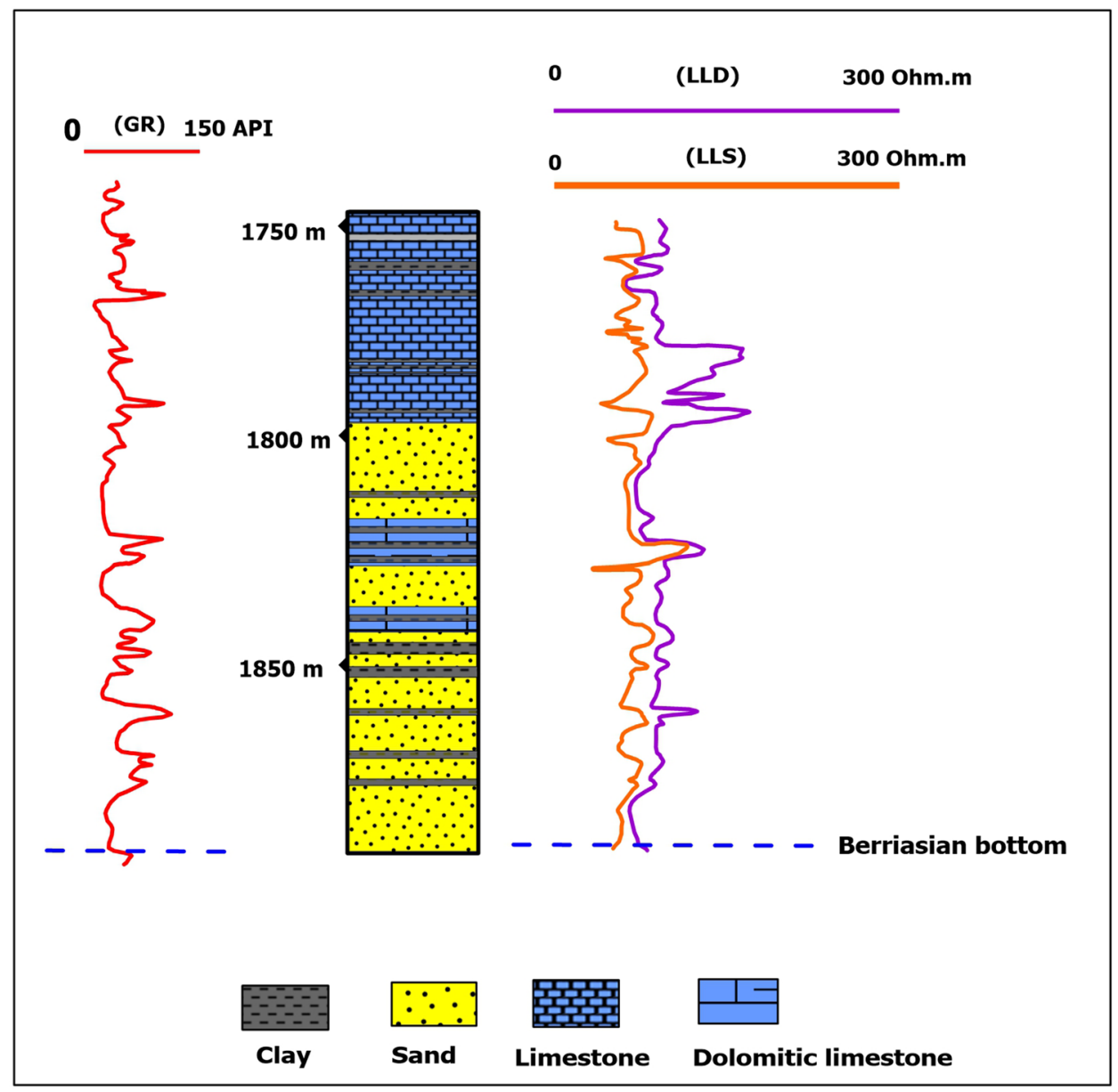


Fig. 6 Characterization of the Tithonian series using well logs (W1 well) two different lithological members: The upper member (from 1750 to $1800 \mathrm{~m}$ ) is composed of limestones, clearly distinguishable by high resistivities (in the order of $150 \Omega \mathrm{m}$ ) and low natural radioactivity values (in the order of 15 API). The few clayey intercalations express antagonistic responses (on average, a resistivity of $11 \Omega \mathrm{m}$ and a natural radioactivity of 105 API).

The basal member (from 1800 to $1900 \mathrm{~m}$ ) is characterized by Gamma ray values mostly ranging from 10 to $30 \mathrm{API}$. It is mainly formed by sandy layers interbedded with dolomitic limestones and clays. Therefore, it cannot assure the seal of the Jurassic petroleum system, While the abundant clayey layers within the Jurassic terminal part (upper Tithonian sequence), matching to frequent high Gamma ray intervals (Fig. 6), can play this role.

At the Tithonian sequence base (Fig. 6), at the depth of 2061-2129 m, the resistivity curves are separated and the "LLD" values reach $200 \Omega \mathrm{m}$, indicating a reservoir lithological ensemble composed chiefly of limestones. This ensemble designated by the reservoir "A" (Fig. 6) surmounts the clayey part of the Kimmeridgian formation which constitutes a potential source rock. It may be also considered a seal rock of the second limestone reservoir "B," identified at the depth of 2495-2740 m depth, at the Kimmeridgian formation base (Fig. 7). The Gamma ray log highlights numerous clayey intercalations within this reservoir.

A third reservoir " $\mathrm{C}$," corresponding to the Oxfordian limestones and dolomitic limestones (Fig. 8), is easily distinguishable by its low and homogeneous natural radioactivity values; the clayey beds are less frequent than in the other recognized reservoirs.

It is worth to note that the low resistivity values characterizing some limestone layers of the reservoir " $\mathrm{C}$ " (for example, from 2840 to $2850 \mathrm{~m}$ ) are caused by brackish imbibed water.

The limit between the Oxfordian and the Callovian series is fixed at $2944 \mathrm{~m}$. It coincides with a remarkable Gamma ray increase (150 API) (Fig. 8).

The Callovian series mainly clayey contain the most important source rock of Metouia block (ETAP 2006), situated at the east of our study area. In this series, the few low natural radioactivity intervals correspond to sandy layers. 
Fig. 7 Characterization of the Kimmeridgian series using well $\operatorname{logs}$ (W1 well)

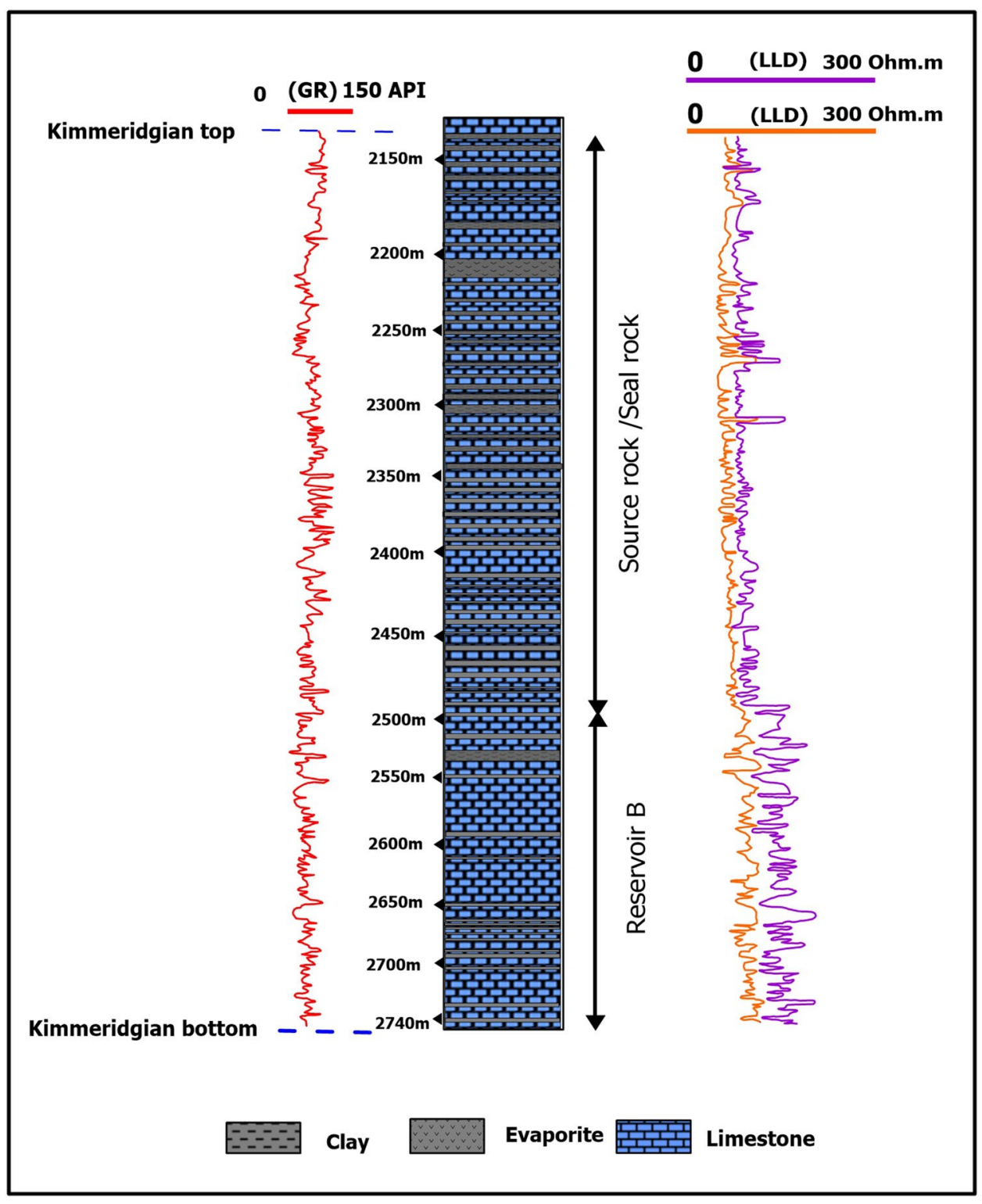

\section{Seismic interpretation contribution}

The isochrones maps in double-time depth (TWT: two-way travel time) and their corresponding isobaths maps in meters (in distance) of the Malm, Dogger and Lias tops show the same tectonic structures. The choice was focused on the maps (Fig. 9) of Malm top since it marks the Jurassic series termination.

Figure $9 \mathrm{a}$ and $\mathrm{b}$ reveals in the center of the study area a high zone characterized by Malm depths ranging from 0.7 to $1.5 \mathrm{~s}$ in double-time (Fig. 9a) and from 1360 to $2110 \mathrm{~m}$ in distance (Fig. 9b) with a clear increase from east to west.

The NE-SW to N-S seismic sections such as L6 (Fig. 10) show that this zone corresponds to an anticlinal structure delimited by two E-W major reverse faults and truncated by others secondary faults mainly oriented NW-SE. It is bordered to the west and north by two subsided areas; in the first which coincides with Chott el Djerid, the Jurassic top is situated between 1.7 and $1.8 \mathrm{~s}$ (Fig. 9a) (between 2360 and $2500 \mathrm{~m}$ ). In the second, correlable with Chott el Fejej, this horizon deepens toward the west; its depth increases (from 1.2 to $1.7 \mathrm{~s}$ ) (from 1860 to $2360 \mathrm{~m}$ ). The southern part of the profile "L10" which cover Chott el Fejej (Fig. 10) shows that the Jurassic series in this zone is affected par normal faults generating a remarkable thickening of the Dogger deposits.

The "L10" northern part (Fig. 10) exposes an anticlinal structure corresponding to the Chareb chain. A major E-W fault draws the limit between this structure and Chott el Fejej. 
Fig. 8 Characterization of the Oxfordian and Callovian series using well logs (W1 well)

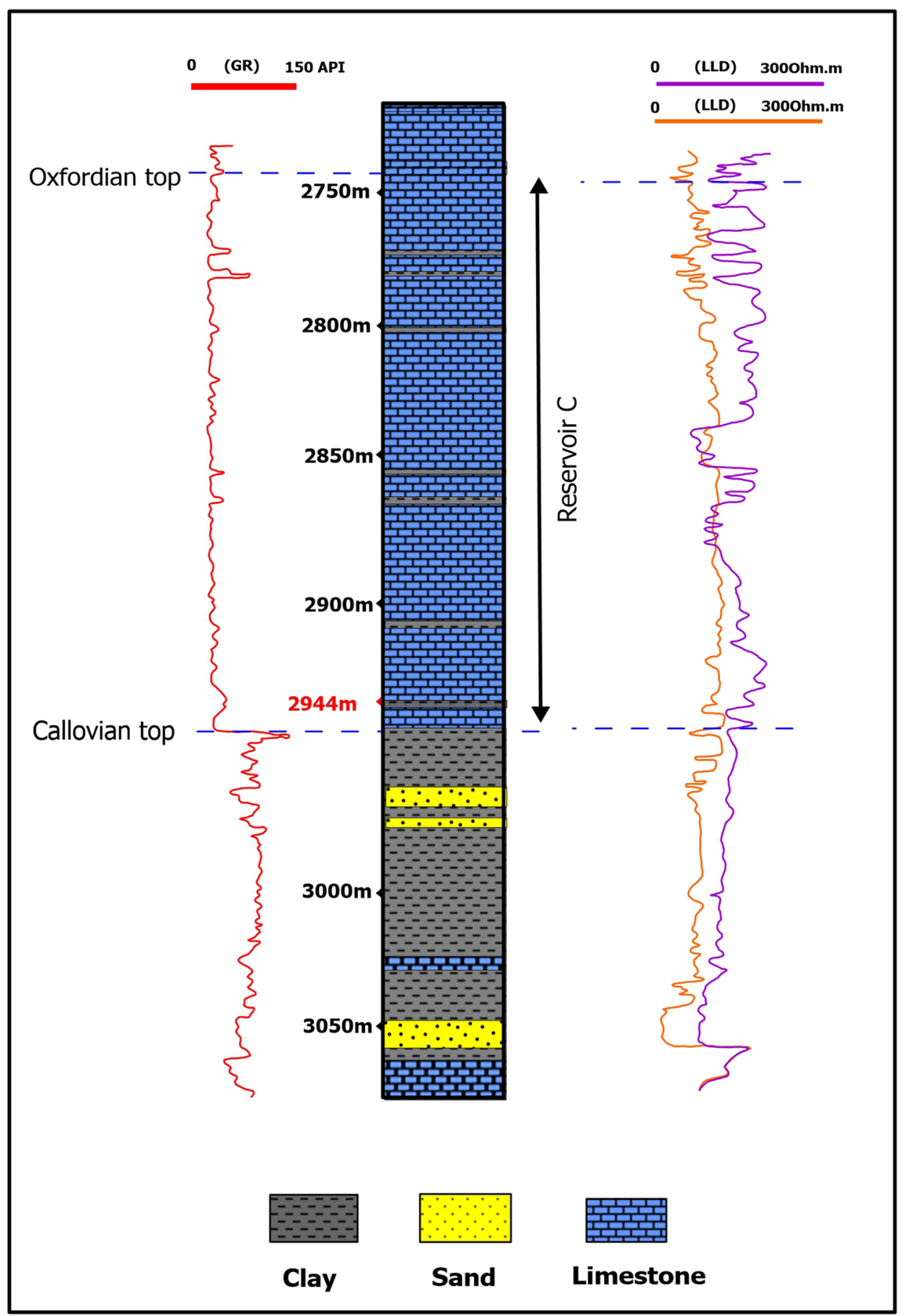

The anticlinal structure, highlighted in the center of the study area, constitutes an excellent trap structure; interesting prospects are precisely delimited in its eastern part. For example, in the profile "L3" (Fig. 11), three prospects (P1, P2 and P3) separated by reverse faults are identified.

Thus, this study has provided more details on the petroleum system despite its limitation by the availability of data. Indeed, the lithological logs and their corresponding loggings in W1 and W2 wells have not reached the Liassic series; thus, we have no information about its composition and reservoir potentiality. Even, W3 well, located outside the study area and used for seismic calibration, has not recognized the base of the Liassic series.

Furthermore, the structural map obtained in this study can be confirmed or even refined if we had gravimetric measurements covering the study area with $1 \mathrm{~km}^{2}$ grid spacing. The accessible measurements are widely spaced, not allowing precise mapping. 


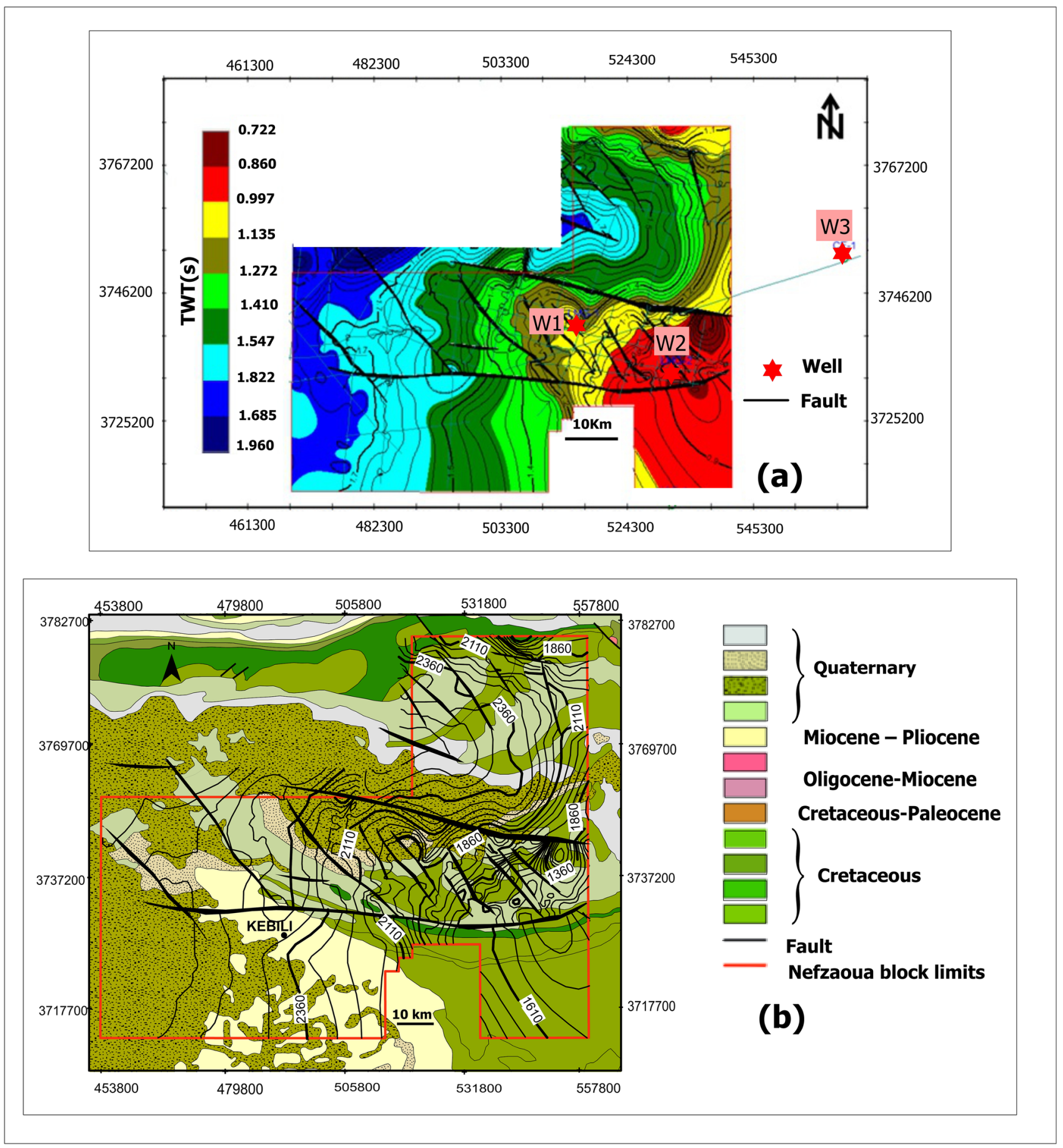

Fig. 9 The top Jurassic series maps. a The isochrones map. b The isobaths map

\section{Summary and conclusions}

Based on well data and seismic reflection profiles, this study allowed characterizing the Jurassic petroleum system in the Chotts zone central part.

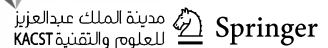

The analysis of the lithological columns and their corresponding well logs shows that:

- The recognized Jurassic deposits contain three main reservoirs composed of fractured carbonates which are precisely Tithonian, Kimmeridgian and Oxfordian in age. 


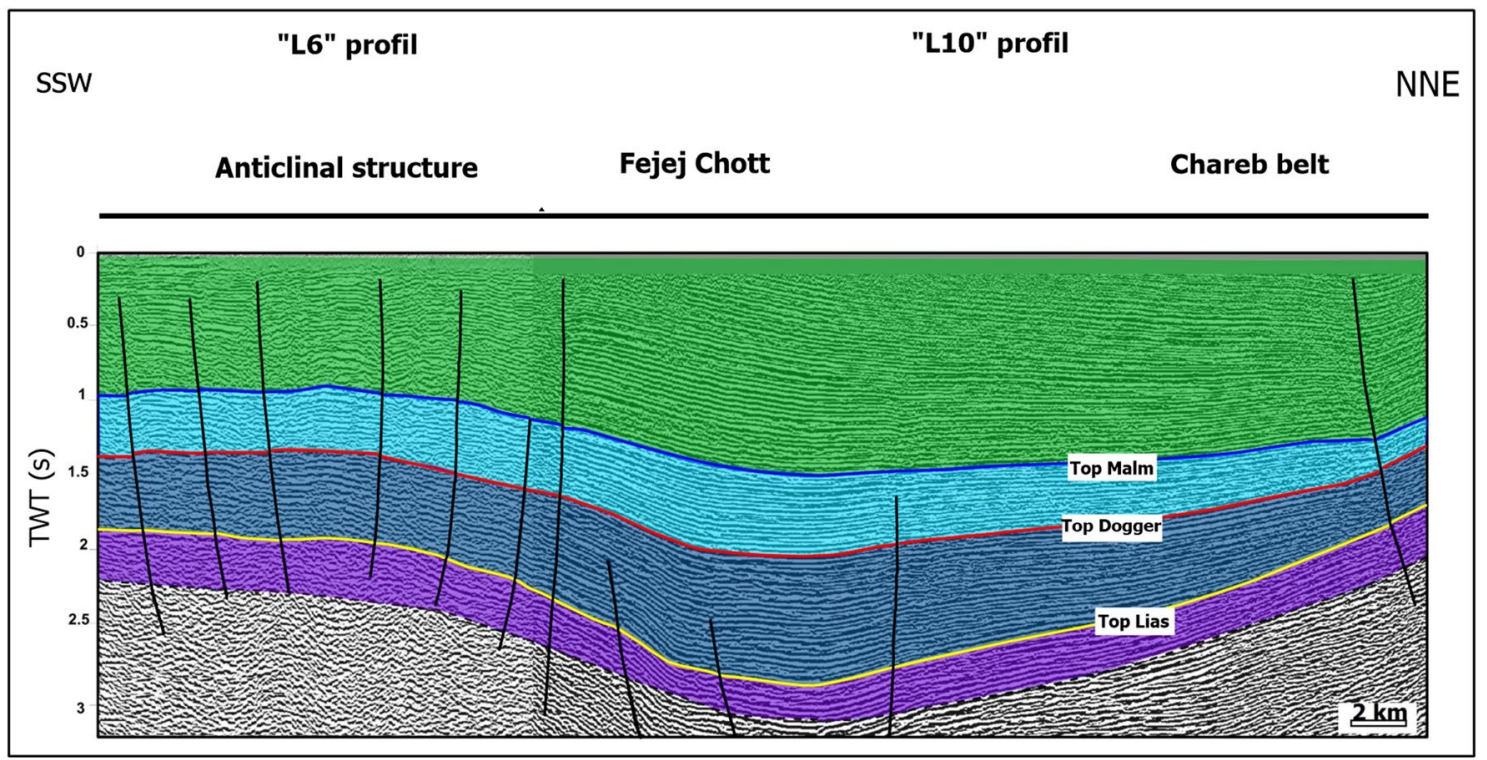

Fig. 10 The interpreted seismic profiles "L6" and "L10"

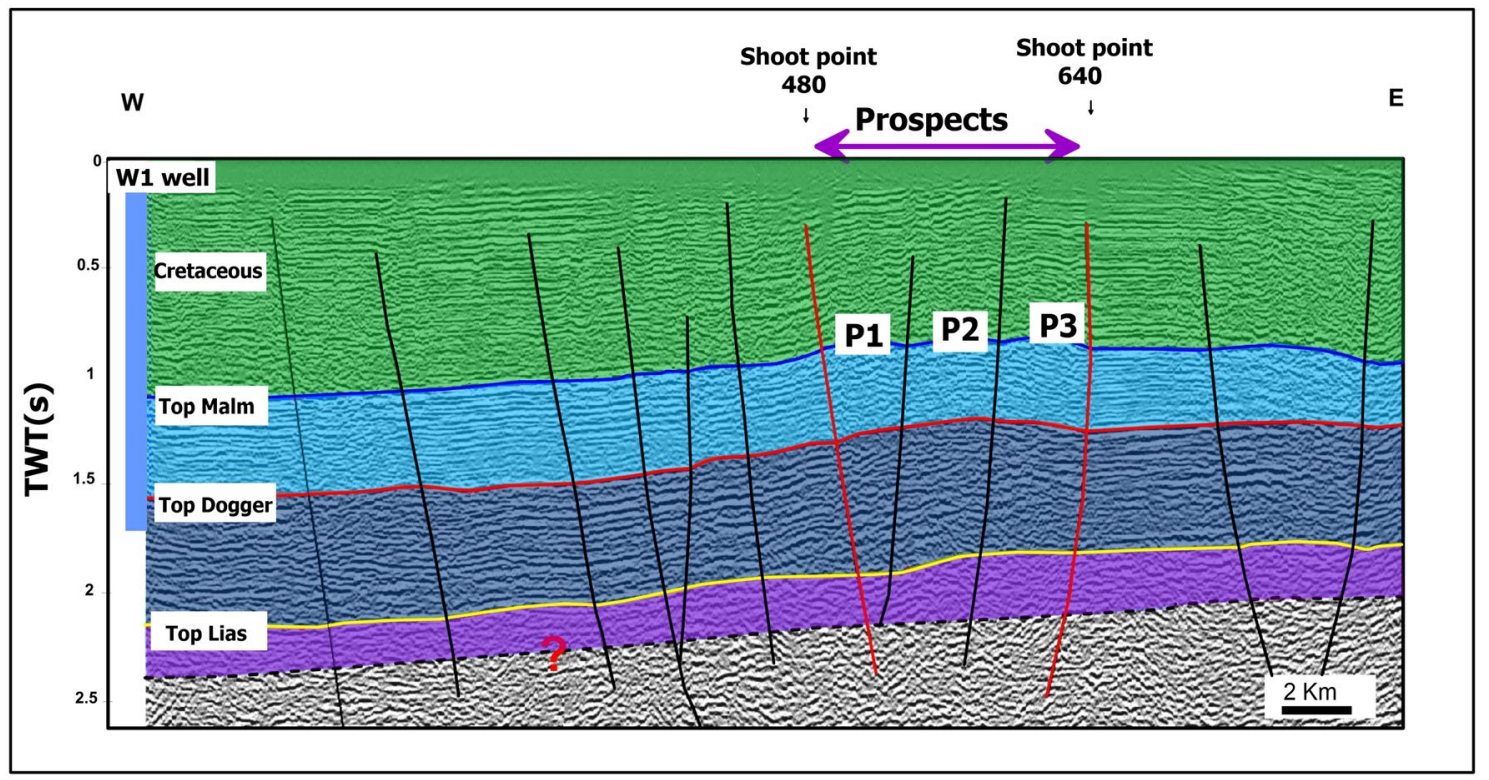

Fig. 11 Prospects identified from seismic interpretation. Example of "L3" profile

- The delimited reservoirs are sealed by the Jurassic clayey intercalations; the Berriasian series is mainly sandy.

- The Kimmeridgian and Callovian clayey formations are the main source rocks.

The seismic interpretation reveals that:

- An important raised structure is identified in the central part of study area.
- The identified structure which corresponds to the Fejej anticlinal is limited by E-W major faults and affected by other less important, oriented NW-SE.

- The Fejej faulted anticlinal constitutes an excellent trap structure; five prospects were identified within this structure.

Acknowledgements The authors thank the "Entreprise Tunisienne d'Activités Pétrolières (ETAP)" for providing seismic and well data. 
Open Access This article is licensed under a Creative Commons Attribution 4.0 International License, which permits use, sharing, adaptation, distribution and reproduction in any medium or format, as long as you give appropriate credit to the original author(s) and the source, provide a link to the Creative Commons licence, and indicate if changes were made. The images or other third party material in this article are included in the article's Creative Commons licence, unless indicated otherwise in a credit line to the material. If material is not included in the article's Creative Commons licence and your intended use is not permitted by statutory regulation or exceeds the permitted use, you will need to obtain permission directly from the copyright holder. To view a copy of this licence, visit http://creativecommons.org/licenses/by/4.0/.

\section{References}

Ameloko AA, Uhegbu GC, Bolujo E (2019) Evaluation of seismic and petrophysical parameters for hydrocarbon prospecting of G-field, Niger Delta, Nigeria. J Petrol Explor Prod Technol 9:2531-2542

Abbes A, Tlig S (1991) Tectonique précoce et sédimentation de la série crétacée dans le Bassin des Chotts (Tunisie du Sud). Géologie Méditerranéenne 18:149-161

Abbes C, Zargouni F (1986) Anatomie d'un couloir de décrochements: le couloir de Hadifa (Chaîne Nord des Chotts-Tunisie). Revue des Sciences de la Terre

Abdeljaoued S (1983) Etude sédimentologique et structurale de la partie orientale de la chaine Nord des Chotts. Thèse de doctorat, Univ. Tunis II

Abdallah H (1987) Le Crétacé supérieur de la chaine Nord des Chotts (Sud de la Tunisie). Biostratigraphie, sédimentologie, diagenèse. Thèse $3^{\text {ème }}$ cycle. Univ. Bourgogne

Bassiouni Z (1994) Theory, measurement and interpretation of well logs. SPE Textbook Series Society of Petroleum Engineers, Texas

Bedir M (1995) Mécanismes géodynamiques des bassins associés aux couloirs de coulissement de la marge atlasique de la Tunisie: sismo-stratigraphie, sismo-tectonique et implications pétrolières. Thèse d'Etat. Univ. Tunis II

Ben Ayed N (1986) Evolution tectonique de l'avant-pays de la chaine alpine de Tunisie du début du Mésozoique `a l’Actuel. Thèse d'Etat. Univ. Paris Sud, centre d'Orsay

Bouaziz S (1995) Etude de la tectonique cassante dans la plate-forme et l'atlas sahariens (Tunisie méridionale): évolution des paleochamps de contraintes et implications géodynamiques. Thèse d'Etat. Univ. Tunis II

Boukadi N, Bedir M, Zargouni F (1998) Geometric and kinematic analyses of pull-apart basins produced by an echelon strikeslip of Gafsa fault systems (Southern Tunisia). Afr Geosci Rev 5:327-338

Burollet PF (1956) Contribution à l'étude stratigraphique de la Tunisie centrale. Ann Mines Géol 18:350

Cagniard L (1962) Reflection and refraction of progressive seismic waves. McGraw Hill, New York

Chihi L, Ben Haj Ali M, Ben Ayed N (1992) Mécanismes et signification structurale du plissement dans les chaines des Chotts (Tunisie méridionale) Analogie avec les plis associés au décrochement E-W de Sbiba (Tunisie centrale). C R Acad Sci 315:1245-1252

Dakhelpour-Ghoveifel J, Shegeftfard M, Dejam M (2019) Capillarybased method for rock typing in transition zone of carbonate reservoirs. J Petrol Explor Prod Technol 9(3):2009-2018

Desbrandes R (1968) Théorie et interprétation des diagraphies. Publications de l'Institut Français du Pétrole, Paris

El Amari A, Gharbi M, Ben Youssef M, Masrouhi A (2016) The structural style of the southern Atlassic foreland in northern Chotts range in Tunisia: field data from Bir Oum Ali structure. Arab J Geosci 9:389
ETAP (2006) Metouia block evaluation. Rapport inédit ETAP

ETAP (2009) Geochemical study of W1 and W2. Rapport inédit ETAP

Fajana AO, Ayuk MA, Enikanselu PA et al (2018) Seismic interpretation and petrophysical analysis for hydrocarbon resource evaluation of 'Pennay' field, Niger Delta. J Petrol Explor Prod Technol 9:1025-1040

Fakraoui M (1990) Etude stratigraphique et structurale des chaines des Chotts (Tunisie méridionale): Evolution géodynamique et cinématique liée à l'accident Sud Atlasique. Thèse $3^{\text {ème }}$ cycle. Univ. Tunis II

Gabtni H, Jallouli C, Mickus C, Turki MM (2011) Geodynamics of the Southern Tethyan Margin in Tunisia and Maghrebian domain: new constraints from integrated geophysical study. Arab J Geosci 6:271-286

Ghanmi M, Potfaj M, Mahjoub K (1988) Carte géologique de Bir Rakeb, au 1/100.000, feuille $n^{\circ} 82$. Service géologique de l'Office National de Mines, Tunisie

Gharbi M, Bellier O, Masrouhi A, Espurt N (2014) Recent spatial and temporal changes in the stress regime along the southern Tunisian Atlas front and the Gulf of Gabes: new insights from fault kinematics analysis and seismic profiles. Tectonophysics 626:120-136. https://doi.org/10.1016/j.tecto.2014.04.00

Mohamed AK, Ghazala HH, Mohamed L (2016) Integration between well logging and seismic reflection techniques for structural analysis and reservoir characterizations, Abu El Gharadig basin, Egypt. NRIAG J Astron Geophys 5:362-379

Nam MJ, Pardo D, Torres-Verdin C (2010) Assessment of Delaware and Groningen effects on dual-laterolog measurements with a self-adaptive hp finite-element method. Geophysics 75:143-149

Olayiwola SO, Dejam MA (2019) Comprehensive review on interaction of nanoparticles with low salinity water and surfactant for enhanced oil recovery in sandstone and carbonate reservoirs. Fuel 241:1045-1057

Rabia MCh (1984) Etude géologique de la région des Chotts par télédétection spatiale, détection de la radioactivité naturelle et analyse hydrogéochimique. Thèse 3ème Cycle, Bordeaux

Rider MH (1996) The geological interpretation of well logs. Gulf Publishing, Houston

Robein E (1999) Vitesse et techniques d'imagerie en sismique réflexion: principes et méthodes. Lavoisier, France

Saboorian-Jooybari H, Dejam M, Chen Z, Pourafshary P (2015) Fracture identification and comprehensive evaluation of the parameters by dual laterolog data. In: Paper SPE 172947, the SPE Middle East unconventional resources conference and exhibition, Muscat, Oman

Saboorian-Jooybari H, Dejam M, Chen Z, Pourafshary P (2016) Comprehensive evaluation of fracture parameters by dual laterolog data. J Appl Geophys 131:214-221

Said A, Baby P, Dominique C, Ouali J (2011) Structure, paleogeographic inheritance, and deformation history of the southern Atlas foreland fold and thrust belt of Tunisia. Tectonics. https://doi. org/10.1029/2011TC002862

Serra O (1985) Diagraphies différées. Bases de l'interprétation Tome 2. Interprétation des données diagraphiques. Bulletin des centres de Recherches. Exploration-Production Elf Aquitaine 7

Tanfous Amri D, Dhahri F, Soussi M, Gabtni H, Bedir M (2017) The role of E-W basement faults in the Mesozoic geodynamic evolution of the Gafsa and Chotts basins, south-central Tunisia. J Earth Syst Sci 126:104. https://doi.org/10.1007/s12040-017-0876-1

Upadhyay SK (2004) Seismic reflection processing: with special reference to anisotropy. Springer, Berlin

Zargouni F (1985) Tectonique de l'Atlas méridionale de Tunisie. Evolution géométrique et cinématique des structures en zone de cisaillement. Thèse d'Etat, Univ. Louis Pasteur

Zouaghi T, Guellala R, Lazzez M, Bédir M, Ben Youssef M, Inoubli MH, Zargouni F (2011) The Chotts Fold Belt of Southern 
Tunisia, North African Margin: Structural Pattern, Evolution, and Regional Geodynamic Implications. New Frontiers in Tectonic Research - At the Midst of Plate Convergence. Intech Vienna. ISBN: 978-953-307-594-5

Zouari H (1995) Evolution géodynamique de l'Atlas centro-méridional de la Tunisie: stratigraphie, analyse géométrique, cinématique et tectono-sédimentaire. Thèse d'Etat. Univ. Tunis
Publisher's Note Springer Nature remains neutral with regard to jurisdictional claims in published maps and institutional affiliations. 